\title{
Leukoencephalopathy-metaphyseal chondrodysplasia syndrome
}

INSERM

\section{Source}

INSERM. (1999). Orphanet: an online rare disease and orphan drug data base.

Leukoencephalopathy-metaphyseal chondrodysplasia syndrome. ORPHA:83629

The association of leukoencephalopathy and metaphyseal chondrodysplasia has been reported in four men from a three-generation family. Onset manifests by spastic paraplegia at the age of 2, followed by tremor, ataxia, optic atrophy, and spastic tetraparesis. Transmission is $\mathrm{X}$-linked and the gene responsible of the disease may be located at Xq25-q27. 